\title{
34 APPLYING OPEN INNOVATION PRINCIPLES FOR TRIGGERING AND ACCELERATING INNOVATIONS: The Experience of Ericsson Spain, 2004 Through 2007
}

\author{
M. Lorenzo \\ Ericsson España \\ Madrid, Spain
}

Abstract Ericsson Spain is an important subsidiary of the Ericsson Group. It hosts one principal research and development center and counts on a strong local marketing, sales, and delivey force to address a vibrant market of telecommunications. A landscape of abundant knowledge including leading universities in Madrid and a growing number of local technology and business partners complete the scene for a company that puts in practice open innovation approaches as introduced by Chesbrough (2003).

The experiences of Ericsson Spain with its recent successful application of open innovation approaches will be described. The resulting improvements to the innovation effectiveness and the lessons learned from these experiences are also outlined.

Keywords Open innovation, innovation ecosystems, R\&D

\section{INCREASING THE FLOWS OF NEW TECHNOLOGIES AND KNOWLEDGE}

As many other technology-intensive companies with decentralized research and development and a global market presence, Ericsson creates subsidiary companies, as is the case of Ericsson Spain, with strong local R\&D organizations, reporting to corporate

Please use the following format when citing this chapter:

Lorenzo, M., 2008, in IFIP International Federation for Information Processing, Volume 287, Open IT-Based Innovation: Moving Towards Cooperative IT Transfer and Knowledge Diffusion, eds. León, G., Bernardos, A., Casar, J., Kautz, K., and DeGross, J. (Boston: Springer), pp. 553-560. 
R\&D functions and business units, and a highly specialized local sales force to address the local market.

Ericsson's product development and delivery processes enable products developed in the Madrid R\&D center to be shipped to all Ericsson markets, Market Unit Iberia (serving Spanish and Portuguese markets) being one of them. The general model is for a technology-push supply chain, where $R \& D$ creates new products for the strategic business units (BUs) and then local market units (MUs) ultimately broker them to the actual end-customers, the local telecom operators and other enterprise customers.

Although working perfectly fine, this model does not exploit all of the synergies that may arise between the R\&D and MU sides of Ericsson Spain, and in the context of a highly demanding local market, it is absolutely key that additional processes for crossborder cooperation are in place in order to really make the difference for both improving success in the local market and enhancing the global portfolio of products.

We will shortly introduce, out of the number of processes to serve this purpose, the processes that genuinely follow open innovation approaches in the sense that the R\&D becomes an open system to MU and local customers, exposing and accessing new knowledge and technologies rather than simply delivering standard products in the standard way.

One of the most successful experiences is a collaboration program for architecting brand-new customer solutions based on emerging technologies. Some technologies have been created in our labs in Madrid and are in the early development stages; others were still at the conceptualization stages, being worked on with other R\&D centers; a few have been created by partners and competitors; most are actually pending business modeling and therefore desperately looking for the input that only market reality can bring. The cooperation between R\&D and MU is articulated in three ways:

- Business (and technology) consulting projects ordered by our local customers. Most times, these projects are actually promoted proactively to our customers as a consequence of the previous exchange of ideas and identification of opportunities based on new R\&D concepts and technologies. Mixed R\&D-MU-customer teams are created and daily and jointly evaluate new alternatives to new or old problems, starting with the architecture and going down to the supporting technologies.

- Prospective customers' RFIs, and RFQs, on new architectures and solutions not available from either our portfolio of products and services or those of other technology providers. For such cooperative efforts, R\&D engineers took the solution architect role inside the team preparing the response. Evaluation of potential partners that could complement our portfolio to satisfy the required needs was essential.

- $\quad$ Early phases of complex integration projects, where R\&D staff directly assisted the customer in creating the best architectural solutions, normally involving products of several providers, onto customers' environments with Ericsson and non-Ericsson technologies in place.

In all cases, the essential exchange was on knowledge and new technologies, either third parties' or exposed pre-commercial technologies under development in Ericsson. The knowledge horizons of both Ericsson and its customers were significantly expanded and a first cooperation usually led to further and broader cooperation. 
The direct benefits of this approach have proven enormous.

- In a number of the new solutions created in this way, several providers could create and capture in return a portion of the value delivered to the customer. Most valuable new partners were identified and now their products are part of the global extended portfolio of Ericsson.

- Quite a few technologies at the lab, some even waiting on the shelf for quite a while, reached an end customer and got the standard product label, therefore becoming innovations actually creating new businesses.

- The positioning of Ericsson as primary integrator of new solutions was significantly strengthened and an increased footprint in new business areas achieved.

- Local customers integrated locally developed and brokered technologies meeting their needs in a timely and accurate manner.

- As a result of the success in this way of working, a few similarly successful projects were also run internationally with other market units.

We judge that such achievements over a period of time, mainly from 2001 to today, confirm that deliberate openness in the innovation process involving internal and external customers as co-innovators, avoiding vertically integrated solutions, and instead creating room for new suppliers of valuable emerging technology, yields better-quality and faster results than other traditional approaches and, even more importantly, enables expansion to adjacent or even radically new business areas and models more easily. Similar experiences in other companies with technology incubation stages in a discovery-incubationacceleration process can be found in Chesbrough (2005).

\section{IDENTIFYING AND PROMOTING EXTERNAL INNOVATION}

Three initiatives will be introduced in this section: Ericsson Mobility World, the IMS Program, and the Application Expert Center.

\subsection{Ericsson Mobility World (Ericsson Partnership Program)}

Content providers rely on Ericsson's competence and channels to reach the mobile market, and we assist application developers in creating and selling innovative and marketable applications. Ericsson Mobility World is a global Ericsson initiative launched in 2001 that helps operators increase traffic on their networks and grow their business. We provide expert assistance, from strategy to market launch, in analyzing the business potential of new mobile services. Before new services are launched, Ericsson Mobility World tests, verifies, and optimizes them for operators' networks and continues to monitor them afterward.

The Ericsson Mobility World Developer Program helps developers' successfully plan, develop, verify, and get applications to operators and their customers. The program 
offers the technical, business, and sales support that developers need to transform ideas into reality. By exposing new technologies to our customers new open business models are identified where Ericsson, the operator, and the partner companies in Mobility world add value and capture return on their investment.

Through the program, developers' applications and content can be included in the Ericsson Mobility World application portfolio and presented to our customers around the world.

The impact of Ericsson Mobility World in the Spanish innovation ecosystem is twofold. Our customers reach an extended portfolio of hundreds of applications and other innovating local companies in the mobility services field can adhere to the program and internationalize their offerings backed by Ericsson's local support and global market presence. In Spain, as well as in many other Ericsson market units, the Mobility World program is a huge success with both indirect and direct returns for Ericsson.

\subsection{IMS Program}

In 2005, Ericsson Spain kicked off a cross-border task force involving business unit network infrastructure, business unit multimedia solutions, and local R\&D staff with the purpose of stimulating the adoption of IMS technology in the local market. As a forerunner in this new technology, it is essential for Ericsson to promote well-coordinated internal teams as well as open external ecosystems of partners, third parties, and institutions contributing with innovations. An important strategy in this task force was to create a critical mass of awareness on the technology in third parties that allowed starting and sustaining open value chains and value networks where Ericsson would try to position them before our customer in at least three roles: preferred IMS infrastructure supplier, preferred IMS services integrator, and preferred supplier/partner of key enabling services such as Presence, Push-to Talk, etc.

This ambition necessarily leaves a lot of room for third parties to contribute and capitalize added value.

We will refer here only to a side branch of actions inspired in open innovation principles that was triggered from this initiative and that mainly had to do with promoting innovation in this field by a local university, UPM (Universidad Politécnica de Madrid).

It would have been an easy temptation to take the closed innovator hat and have thought that Ericsson, as non-disputed leader in the IMS market, was the one to train the UPM researchers and provide them with our ideas, guidance, and funding so that they could develop research-stage prototypes, potentially adding some technical or marketing value. But we were lucky to try other approaches based on open innovation principles.

We certainly did train the UPM researchers on Ericsson IMS systems and also provided them with our tools devised for creation of IMS-based services - and of all this was actually an important part of extending awareness on the technology and helping develop new skills required for creating new services. However, we did not specify or order the research work to be done. Instead we gave them the freedom to create from scratch new services on top of IMS and we obtained amazing results. Based on the core competency and knowledge of one of the UPM teams engaged in this initiative, they 
came up with a proposal combining other (Web2.0) technologies that they mastered and pioneered with IMS in order to create new technology proposals compatible with a variety of target business models they were not aware of or even concerned with.

The investment in UPM, therefore, paid off. The technology developed has been showcased ever since to a number of prospective customers and is one of the best IMS openers, showing the potential and advantages of combining IMS with other widespread new technologies. Several further research and innovation projects have evolved the ideas and there is on-going internal evaluation for product development in a new area for Ericsson.

Beyond the IMS program scope, this was but one successful innovation cell project with UPM following the open model. The power of combining deep expertise in new technologies developed in the research groups at UPM with open basic technologies created by industry was demonstrated. The superiority of this open collaboration model, where both parties (industry and university) openly contribute and complement each other from their core competencies and knowledge over closed models where the university merely would have played an on-demand, externally directed contract research role, is also clear.

\subsection{IMS Application Expert Center}

As part of the Ericsson Mobility World Development Program, an on-going program in Ericsson's Market Unit Iberia since May 2006, is the IMS Application Expert Center, which further develops the partnering-for-innovation approach and builds on similar strategic principles to those introduced above for the IMS program.

Content and applications providers will have the opportunity to propose new ideas to Ericsson and to develop new services in specific areas. They will also get assistance in realizing these ideas and taking them to market as products that can be sold to operators all over the world. Operators will get a unique channel for close contact with the developer community, enabling faster conceptualizing and development of future services. The model allows operators to get a glimpse of technologies, services, and concepts launched all over the world, leveraging on the Ericsson Mobility World network that is present in 35 countries.

An Expert Center is also a way for operators to connect with new services, differentiating them from competitors. In Italy, the Expert Center provides operators with a live environment where they can prototype and test new applications and concepts from developers in order to have a concrete basis for making decisions.

This initiative, therefore, activates a development community and creates an IMS services ecosystem that is beneficial for our customers, for third parties joining in, and ultimately for Ericsson in the roles it is strategically seeking to play in the long and open value chain of SIP services. The IMS Application Expert Center actively showcases IMS-based applications created by local third parties as well as internally or in open cooperation with new partners and research institutions, as is the case for the local collaboration with UPM. Most of the open innovation principles inspire and motivate this initiative, which is also in place in other Ericsson market units. 


\section{SHARED R\&D WITH CUSTOMER PARTNERS: OPENING OUR RESEARCH TO CUSTOMERS}

Another far-reaching initiative in innovation management at Ericsson Spain is a program of alliances with key customers for engaging in innovation from early research stages to commercialization. This is a rich type of cooperation protected by mutual nondisclosure agreements, where both Ericsson and the customer contribute with new concepts, technologies, and R\&D effort.

Our R\&D becomes an open system to the customer. In particular, our local and global research outcomes are exposed and become a piece to play with in joint innovation projects that seek to test those technologies in business contexts that are yet to be identified. Business models are worked together for the solutions researched and it is up to each party to further define their contribution or the involvement of other parties.

With the set-up model, both parties retain rights over the R\&D artifacts they share and it is the exposure of technology research and business opportunities to each other that helps the other party to tune and steer their internal innovation.

Of course, some ideas are created jointly as a result of the dialog, and some enter the patent process, separately or jointly, but it is not exclusion but inclusion principles what motivates deeper and further collaboration.

After the three first projects with one customer engaged in this model, we have verified the trend to share and jointly identify more and more opportunities for collaboration and more and more partners, which creates a positive domino effect in the speed of innovation implementation and adoption. We have also verified that joint projects mutate at some point in time from shared R\&D prospective projects to business unit supported projects at both ends of the collaboration and therefore the innovation time-tomarket is significantly improved.

\section{PROMOTING AND LEVERAGING UNIVERSITY RESEARCH FOR CREATING AND SPEEDING INTERNAL INNOVATIONS}

We can also report two relevant local cases where university-initiated research on apparently noncore businesses for Ericsson is followed by a technology transfer and spinin.

One is kept aside for confidentiality issues. The other one is the case of the knowledge transfer into Ericsson Research of methods, practices, and technology for advanced data mining developed by Universidad Carlos III de Madrid (UCIIIM). Over 10 years of continued research has taken UCIIIM to their leadership position in this field. Ericsson Spain, as result of technology surveillance and networking activities, knew of this technology potential and devised new applications. A match with potential new Ericsson business models was found and acknowledged by our corporate strategic research organization (Ericsson Research). As a result, an intensive and extensive technology transfer process was initiated in order to spin in their technology and base new 
products on it. In one year, a go-ahead decision for a product in the field has been granted in Ericsson and it is UCIIM, not Ericsson, that has spent long years in growing this technology to its current state and potential. Of course, the potential applications and interactions with other systems envisioned by Ericsson were not guessed by UCIIM and this again proves the power of open innovation.

\section{CREATING ALTERNATIVE PATHS FOR DEVELOPMENT AND COMERCIALIZATION}

We have finally identified the need to strengthen efforts in finding alternative paths for ideas we are unsure how to exploit. We are practicing an approach for virtually spinning out high-risk/high-potential innovations with several potential business models. Since several business models are possible, they might actually compete with each other and in principle Ericsson could more easily support and implement only one of them, so the uncertainty may have a big effect that is not easy-probably not even possible - to anticipate. Such uncertainty is better cared for with a extrovert approach that would be difficult to secure should the project be kept internal.

One of our largest technology innovation projects on-going today follows this approach, which guarantees independence and autonomy for the team to explore and validate the idea and develop a new core technology without concerns on the funding that is guaranteed by Ericsson after a complex decision process involving a number of stakeholders. Rounds of verification, where internal sponsors play the internal venture capital role and the project team shows progress à la startups, secure alignment with the high expectations set on these projects and provides the basis for further rounds of funding.

\section{CONCLUSIONS}

The application of open innovation approaches is not per se a guarantee of success but allows Ericsson to promote and try out innovations that otherwise would be parked forever or not even generated at all. A number of open innovation approaches have been illustrated in the previous experiences. Such approaches seem to mix well with the dynamics of the market and the industry of information technology and communications in Spain.

We have reviewed how new business opportunities based on R\&D knowledge and technologies at early stages can be generated, accelerating the pace of the innovation process with near-market research.

We have seen how nonintrusive funding of university research may create higher value than large research contracts, an investment that sustains the base of the open innovation paradigm, which is the promotion of external complementary creativity in the environment. Return on investment may, however, not be guaranteed unless a critical mass of companies fund this type of research with an open approach.

The efforts to create ecosystems for new technology diffusion where several players can create value and have business chances deserve special attention. These players 
(third parties, business partners, and even competitors) will play a critical role as innovators and the environment (institutions, universities, consultancy companies, etc.) need to become aware and stimulated as well in order to provide a solid background for their success.

\section{References}

Chesbrough, H. 2003. Open Innovation: The New Imperative for Creating and Profiting from Technology, Boston: Harvard Business School Press.

Chesbrough, H. 2005. Open Innovation: Researching a New Paradigm, New York: Oxford University Press.

\section{About the Author}

Manuel Lorenzo is head of the Technology \& Innovation Unit of Ericsson Spain. His unit performs IPR Management and Strategic Research integrated in Ericsson's Corporate Technology function, as well as business innovation projects performed in coordination with the local Market Unit (Spain and Portugal), as well as with national and European institutions and technology and busienss partners. Manuel holds a B.Eng. degree in Telecommunications from Universidad Politécnica de Madrid with a specialization in Computer Networks. Since 1994, he has developed his professional career in Ericsson (Spain, Sweden, and Ireland) in several technology and business fields, including Telecom Management, Mobile Internet Infrastructure and Applications, Network Databases and Digital Identities. He is a member of Ericsson-wide communities and initiatives, including the Ericsson Global Innovation Forum, and actively promotes networking among companies as well as between the industrial and academic worlds with the aim of exchanging, extending, and applying knowledge and best practices in management of technology and innovation. Manuel can be reached at manuel.lorenzo@ericsson.com. 